\title{
Karakteristik Genus Bakteri Pada Karkas Ayam Broiler Dari Swalayan di Kota Pontianak
}

\author{
Prianti $^{1}$, Rahmawati ${ }^{1}$, Diah Wulandari Rousdy ${ }^{1}$ \\ Program Studi Biologi, Fakultas MIPA, Universitas Tanjungpura, Jln. Prof. Dr. H. Hadari Nawawi, Pontianak. \\ Email korespondensi : prianti1293@gmail.com
}

\begin{abstract}
The availability of nutrients in chicken carcasses can cause chicken meat to be an excellent medium for the growth of pathogenic and non-pathogenic bacteria. This study aims to determine the characteristics of the bacterial genus in broiler chicken carcasses from supermarkets in Pontianak City. Based on the results of the study found 23 bacterial isolates in broiler chicken carcass samples from supermarkets in Pontianak City, which included members of the Aeromonas, Acetobacter, Alcaligenes, Amphibacillus, Bacillus, Brevibacterium, Camphylobacter, Carnobacterium, Erwinia, Erysipelothrik, Eubacterium, Hafnia, Kluyvera, Klebsiella, Kurthia, Lactobacillus, Listeria, Proteus, Pseudomonas, Shigella, Sporolactobacillus, Serratia, and Yersinia.
\end{abstract}

Key word: Bacterial, Chicken

\section{PENDAHULUAN}

Pemenuhan kebutuhan pangan hewani dikalangan masyarakat semakin hari semakin meningkat khususnya produk pangan daging ayam broiler. Hal ini terjadi karena karkas ayam broiler dapat memenuhi kebutuhan gizi masyarakat khususnya protein hewani, selain itu karkas ayam juga memiliki beberapa keunggulan selain nilai gizinya yang baik untuk pertumbuhan, karkas ayam ini juga banyak dikonsumsi oleh segala lapisan konsumen sehingga pemasokan produk pangan daging ayam sangat mudah untuk diperoleh baik itu di pasar tradisional maupun pasar swalayan, dari sisi ekonomi juga karkas ayam memiliki harga yang relatif murah dibandingkan dengan daging yang lain (Triyantini et al.,2000).

Meningkatnya kebutuhan daging ayam yang dibutuhkan konsumen, menyebabkan pemasokan produk daging yang dijual di pasar tradisional dan pasar swalayan sangat diperhatikan terutama penyedian produk yang aman bagi konsumen. Hal ini dilakukan agar produk yang dijual terhindar dari jenis-jenis kerusakan terutama oleh mikroba karena nilai gizi yang dihasilkan oleh daging merupakan kebutuhan gizi yang baik bagi mikroba. Menurut Albiner (2002) pertumbuhan mikroba pada produk pangan daging dapat menimbulkan perubahan fisik atau kimia yang dapat menyebabkan produk pangan tidak layak untuk dikonsumsi, hal ini terjadi karena pembusukan yang disebabkan oleh mikroba. Kerusakan bahan pangan apabila dikonsumsi maka dapat menyebabkan penyakit berbahaya seperti food borne deseasis, tifus, kolera, disentri, dan diare akut yang tersebar melalui bahan pangan. Oleh karena itu, untuk menghindari terjadinya kontaminasi mikroba maka perlu dilakukan sistem sanitasi yang baik pada saat distribusi daging ayam.

Kebutuhan pangan menjadi hal yang utama bagi masyarakat karena merupakan sumber kebutuhan yang alamiah, sehingga tidak sebagian orang yang akan berbelanja dengan mencari produk yang terbaik, sebagian masyarakat juga akan memilih tempat yang nyaman dan sistem higenisnya baik misalnya kebutuhan produk pangan yang dijual di pasar swalayan yang telah tertata dengan rapi dan dijajakan di tempat-tempat khusus, dibandingkan dengan pasar tradisional yang sistem higenisnya masih kurang diperhatikan dan barang yang dijual masih bercampur-campur dengan produk-produk lain (Irawati \& Hanurawaty, 2014). Tetapi hal ini tidak menutup kemungkinan bahwa produk pangan daging ayam broiler yang dijual di pasar swalayan terhindar dari adanya kerusakan yang disebabkan oleh berbagai kontaminasi oleh mikroba. Oleh karena itu perlu dilakukan penelitian tentang karakteristik bakteri pada karkas ayam broiler dari swalayan di Kota Pontianak.

\section{BAHAN DAN METODE}

\section{Waktu dan Tempat Penelitian}

Penelitian ini dilaksanakan pada bulan Desember 2017 sampai dengan Februari 2018. Sampel karkas ayam diambil dari pasar swalayan yang ada di Kota Pontianak. Isolasi, karakteristik, dan identifikasi 
dilakukan di Laboratorium Mikrobiologi, Fakultas Matematika dan Ilmu Pengetahuan Alam, Universitas Tanjungpura Pontianak.

\section{Alat dan Bahan}

Peralatan yang digunakan dalam penelitian ini adalah autoklaf, bunsen, penghalus, cawan petri, erlenmeyer, gelas objek, hygrometer, inkubator, jarum inokulasi (ose), kertas $\mathrm{pH}$, mikroskop, pisau, pinset, pipet tetes, plastik pembungkus, rak tabung, sentrifugasi, spuit, timbangan analitik, tabung reaksi, dan vortex.

Bahan yang digunakan adalah ayam broiler, alkohol $70 \%$, spiritus, media Nutrien Agar (NA), Sulfide Indole Motility (SIM) Agar, Triple Sugar Iron Agar (TSIA), Simmons Citrate Agar (SCA), urea Christensen Agar, reagen kovac, Hidrogen peroksida $\left(\mathrm{H}_{2} \mathrm{O}_{2}\right) 3 \%$, reagen pewarnaan gram (lugol kristal violet, larutan iod, alkohol-aseton dan safranin).

\section{Prosedur Kerja}

Pengambilan Sampel

Pengambilan sampel karkas ayam broiler dilakukan di tiga pasar swalayan di Kota Pontianak. Karkas ayam dibeli sebanyak satu ekor dari setiap pasar swalayan, sehingga diperoleh 3 ekor karkas ayam utuh. Kemudian sampel daging ayam dimasukkan ke dalam plastik steril dan disimpan di dalam cooler box. Selanjutnya sampel dibawa ke Laboratorium Mikrobiologi, Fakultas Matematika dan Ilmu Pengetahuan Alam, Universitas Tanjungpura Pontianak, untuk dianalisis bakteri yang mengkontaminasi karkas ayam tersebut.

\section{Isolasi Bakteri}

Sampel karkas ayam broiler yang dibeli di setiap pasar swalayan dipotong kecil-kecil dan dikompositkan dengan memblender daging ayam hingga halus, sehingga dari setiap pasar diperoleh satu sampel. Hasil komposit daging ayam ditimbang dan diambil $10 \%$ dari berat total setiap sampel. Sampel dimasukkan ke dalam plastik dan ditambahkan $90 \mathrm{ml}$ suspensi steril. Selanjutnya dilakukan pengenceran sebanyak dua kali ulangan dengan cara diambil $1 \mathrm{ml}$ suspensi lalu dimasukkan ke dalam $9 \mathrm{ml}$ akuades steril untuk memperoleh pengenceran $10^{-1}$, lalu dilanjutkan dengan pengenceran $10^{-2}, 10^{-3}, 10^{-4}$ dan $10^{-5}$, dengan cara mengambil $1 \mathrm{ml}$ di setiap pengenceran dan dipindahkan ke tabung pengenceran berikutnya yang berisi $9 \mathrm{ml}$ akuades steril (Waluyo, 2008)

Sampel dari pengenceran $10^{-3}, 10^{-4}$ dan $10^{-5}$ diambil sebanyak $1 \mathrm{ml}$ dari setiap pengenceran dan dimasukan ke dalam cawan petri, lalu ditambahkan $\pm 20 \mathrm{ml}$ Nutrien Agar (NA) yang sudah didinginkan hingga suhu $45^{\circ} \mathrm{C} \pm 1^{\circ} \mathrm{C}$. Sampel dan media agar dihomogenkan, setelah itu didiamkan sampai media membeku, lalu diinkubasi pada temperatur $34^{\circ} \mathrm{C}$ $36^{\circ} \mathrm{C}$ selama 24 jam dengan meletakkan cawan pada posisi terbalik. Selanjutnya koloni bakteri yang tumbuh diamati karakter morfologisnya.

\section{Karakterisasi Bakteri dari Karkas Ayam Broiler}

Isolat bakteri dikarakterisasi berdasarkan pengamatan karakter morfologis koloni, dan sel, karakteristik fisiologis berdasarkan uji biokimia. Identifikasi bakteri dari karkas ayam broiler mengacu pada buku kunci determinasi Bergey's manual of determinative bacteriology (Holt et al.,1994), Cowan and Steel's manual for the identification of medical bacteria (Barrow \& Feltham,1993).

\section{Parameter Pengamatan dan Analisis Data}

Parameter yang diamati dalam penelitian ini adalah karakter genus bakteri berdasarkan pengamatan morfologis koloni dan sel bakteri, serta karakter fisiologis berdasarkan uji biokimia. Data dianalisis secara deskriptif berdasarkan hasil identifikasi. Data disajikan dalam bentuk tabel dan foto (gambar).

\section{HASIL DAN PEMBAHASAN \\ Hasil}

Berdasarkan hasil pengamatan secara makrokopis diperoleh sebanyak 35 isolat dengan karakter yang berbeda. Bentuk sel bakteri pada daging ayam broiler bervariasi, yaitu berbentuk bulat (Coccus), oval (Coccobacillus) dan batang (Bacillus). 22 isolat bakteri bersifat gram positif dan 13 lainnya bersifat gram negatif (Gambar 1 dan Tabel 1) 

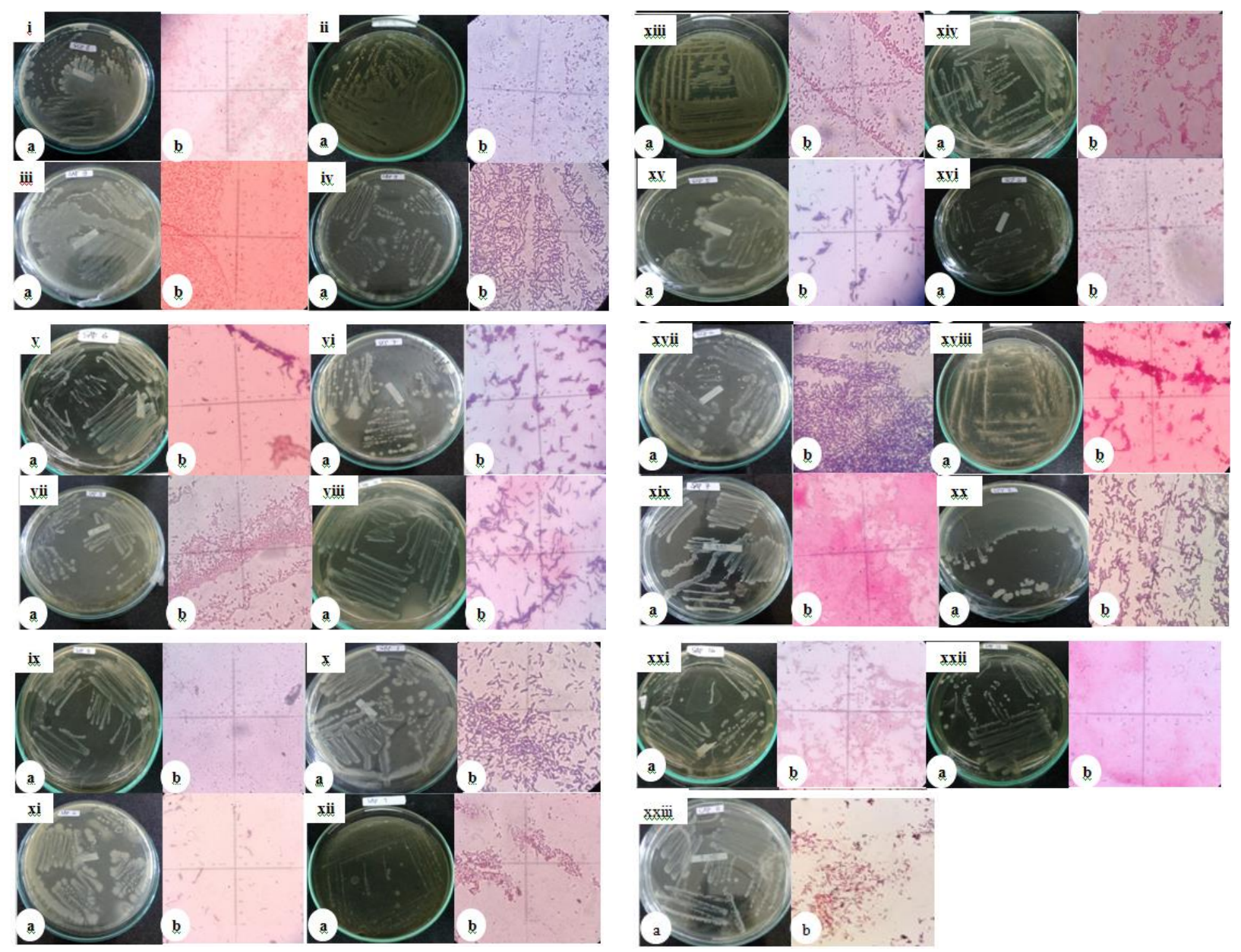

Gambar 1. Karakter Fisiologis Bakteri pada Karkas Ayam Broiler. (a) Makroskopis, (b) Mikroskopis (i) Aeromonas, (ii) Acetobacter, (iii) Alcaligenes, (iv) Amphibacillus, (v) Bacillus, (vi) Brevibacterium, (vii) Camphylobacter, (viii) Carnobacterium, (ix) Erwinia, (x) Erysipelothrik, (xi) Eubacterium, (xii) Hafnia, (xiii) Kluyvera, (xiv) Klebsiella, (xv) Kurthia, (xvi) Lactobacillus, (xvii) Listeria, (xviii) Proteus, (xix) Pseudomonas, (xx) Shigella, (xxi) Sporolactobacillus, (xxii) Serratia, dan (xxiii)Yersinia. 
Protobiont (2018) Vol. 7 (3) : 24 -35 (Tabel 1)

Berikut hasil pengamatan secara makroskopis dan mikroskopis dan fisiologis (uji biokimia) bakteri karkas ayam broiler yang dijual di Swalayan di Kota Pontianak

Tabel 1. Karakter Morfologis dan Fisiologis Isolat Bakteri pada Karkas Ayam Broiler yang dijual di Pasar Swalayan Kota Pontianak

\begin{tabular}{|c|c|c|c|c|c|c|c|c|c|c|c|c|c|c|c|c|}
\hline NO & Genus & $\begin{array}{l}\text { Kode } \\
\text { Isolat }\end{array}$ & Warna & Bentuk & Tepian & Elevasi & Gram & $\mathbf{K}$ & $\mathbf{O}$ & TSIA & Gas & H2S & In & Mo & Urea & SCA \\
\hline 1. & Aeromonas & $\mathrm{C} 8$ & Putih & Sirkular & Lobate & Convex & - & + & + & $\mathrm{A} / \mathrm{A}$ & - & + & + & + & - & - \\
\hline 2. & Acetobacter & $\mathrm{C} 4$ & Putih & Sirkular & Entire & Convex & - & + & - & $\mathrm{A} / \mathrm{A}$ & - & + & + & + & - & - \\
\hline 3. & Alcaligenes & A9 & Putih & Rhizoid & Lobate & Raised & - & + & + & $\mathrm{A} / \mathrm{A}$ & + & - & - & + & + & - \\
\hline 4. & Amphibacillus & B9 & Putih & Iregular & Lobate & Flat & + & - & - & $\mathrm{A} / \mathrm{A}$ & - & - & - & + & + & - \\
\hline \multirow[t]{10}{*}{5.} & Bacillus & sp 1 & Putih & sirkular & Lobate & Flat & + & + & + & $\mathrm{A} / \mathrm{A}$ & - & - & - & + & - & - \\
\hline & Bacillus & sp 2 & Putih & Sirkular & Lobate & Flat & + & + & + & $\mathrm{A} / \mathrm{A}$ & - & - & - & + & - & - \\
\hline & Bacillus & sp 3 & Putih & Iregular & Lobate & Flat & + & + & + & $\mathrm{A} / \mathrm{A}$ & - & - & - & + & - & - \\
\hline & Bacillus & sp 4 & Putih & Iregular & Lobate & Raised & + & + & + & $\mathrm{A} / \mathrm{A}$ & - & - & - & + & - & - \\
\hline & Bacillus & sp 5 & Bening & Iregular & Entire & Flat & + & + & + & $\mathrm{A} / \mathrm{A}$ & - & - & - & + & - & - \\
\hline & Bacillus & sp 6 & Bening & Iregular & Entire & Flat & + & + & + & $\mathrm{A} / \mathrm{A}$ & - & - & - & + & - & - \\
\hline & Bacillus & sp 7 & Putih & Sirkular & Entire & Flat & + & + & - & $\mathrm{A} / \mathrm{A}$ & - & - & - & + & - & - \\
\hline & Bacillus & sp 8 & Putih & Sirkular & Entire & Flat & + & + & - & $\mathrm{A} / \mathrm{A}$ & - & - & - & + & - & - \\
\hline & Bacillus & sp 9 & Putih & Sirkular & Entire & Flat & + & + & - & $\mathrm{A} / \mathrm{A}$ & - & - & - & + & - & - \\
\hline & Bacillus & sp 10 & $\begin{array}{l}\text { Putih } \\
\text { susu }\end{array}$ & Sirkular & Entire & Flat & + & + & - & $\mathrm{A} / \mathrm{A}$ & - & - & - & + & - & - \\
\hline 6. & Brevibacterium & $\mathrm{C} 7$ & Putih & Iregular & Lobate & Flat & + & + & + & $\mathrm{A} / \mathrm{A}$ & - & - & - & - & - & - \\
\hline 7. & Camphilobacter & A3 & $\begin{array}{l}\text { Putih } \\
\text { krem }\end{array}$ & sirkular & Lobate & Raised & - & + & + & $\mathrm{B} / \mathrm{B}$ & - & - & - & + & + & - \\
\hline 8. & Carnobacterium & A13 & Putih & Sirkular & Entire & Flat & + & - & + & $\mathrm{A} / \mathrm{A}$ & + & - & - & + & - & - \\
\hline 9. & Erwinia & A8 & Putih & Iregular & Lobate & Flat & - & + & - & $\mathrm{A} / \mathrm{A}$ & - & - & - & + & - & - \\
\hline 10. & Erysipelothrik & B3 & Bening & Rhizoid & Filamenteus & Flat & + & - & - & $\mathrm{A} / \mathrm{A}$ & - & - & - & - & - & - \\
\hline \multirow[t]{3}{*}{11.} & Eubacterium & B6 & Putih & Iregular & Filamenteus & Convex & + & - & - & $\mathrm{A} / \mathrm{A}$ & - & - & - & + & - & - \\
\hline & Eubacterium & B6 & Putih & Iregular & Filamenteus & Convex & + & - & - & $\mathrm{A} / \mathrm{A}$ & - & - & - & + & - & - \\
\hline & Eubacterium & B6 & Putih & Iregular & Filamenteus & Convex & + & - & - & $\mathrm{A} / \mathrm{A}$ & - & - & - & + & - & - \\
\hline 12. & Hafnia & $\mathrm{A} 1$ & $\begin{array}{l}\text { Putih } \\
\text { susu }\end{array}$ & sirkular & Entire & Raised & - & + & - & $\mathrm{A} / \mathrm{A}$ & + & - & - & + & - & - \\
\hline 13. & Kluyvera & $\mathrm{C} 3$ & Putih & Sirkular & Entire & Flat & - & + & - & $\mathrm{A} / \mathrm{A}$ & + & - & + & + & - & + \\
\hline 14. & Klebsiella & $\mathrm{A} 2$ & Putih & Iregular & Entire & Raised & - & + & + & $\mathrm{A} / \mathrm{A}$ & - & - & - & - & - & + \\
\hline
\end{tabular}


Protobiont (2018) Vol. 7 (3) : $24-35$

Lanjutan. Tabel 1. Karakter Morfologis dan Fisiologis Isolat Bakteri pada Karkas Ayam Broiler yang dijual di Pasar Swalayan Kota Pontianak

\begin{tabular}{|c|c|c|c|c|c|c|c|c|c|c|c|c|c|c|c|c|}
\hline 15. & Kurthia & $\mathrm{C} 5$ & Putih & Iregular & Rhizoid & Flat & + & + & - & $\mathrm{A} / \mathrm{A}$ & - & + & + & + & - & - \\
\hline 16. & Lactobacillus & C6 & Putih & Iregular & Entire & Convex & + & - & - & $\mathrm{A} / \mathrm{A}$ & - & - & + & + & - & - \\
\hline 17. & Listeria & C10 & Putih & Sirkular & Rhizoid & Flat & + & + & - & $\mathrm{A} / \mathrm{A}$ & - & - & + & + & - & - \\
\hline 18. & Proteus & C9 & Putih & Sirkular & Lobate & Convex & - & + & - & $\mathrm{A} / \mathrm{A}$ & - & + & + & + & + & - \\
\hline 19. & Pseudomonas & A7 & Putih & Iregular & Lobate & Convex & - & - & - & $\mathrm{A} / \mathrm{A}$ & - & - & - & - & - & - \\
\hline 20. & Shigella & $\mathrm{C} 1$ & Bening & Iregular & Lobate & Convex & - & + & - & $\mathrm{A} / \mathrm{A}$ & - & - & - & - & - & - \\
\hline & Shigella & C1 & Bening & Iregular & Lobate & Convex & - & + & - & $\mathrm{A} / \mathrm{A}$ & - & - & - & - & - & - \\
\hline 21. & Serratia & A12 & Krem & Sirkular & Entire & Convex & - & + & - & $\mathrm{A} / \mathrm{A}$ & - & - & - & + & - & + \\
\hline 22. & Sporolactobacillus & A16 & Putih & Sirkular & Entire & Flat & + & - & + & $\mathrm{A} / \mathrm{A}$ & + & - & - & + & + & - \\
\hline 23. & Yersinia & A11 & Putih & Rhizoid & Filamenteus & Raised & + & + & + & $\mathrm{A} / \mathrm{A}$ & - & - & - & + & + & + \\
\hline
\end{tabular}

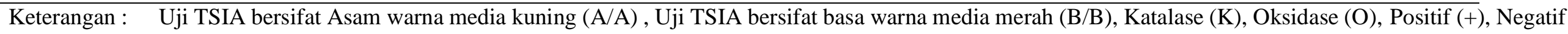
(-), Indol (In), Motil (Mo) Sirkular (Bulat), Iregular (tidak beraturan, bertepi), Rhizoid (seperti akar pertumbuhan menyebar), Entire (rata), Filamenteus (tepian seperti benang-benang), Flat (permukaan koloni rata dengan medium), Raised (permukaan koloni rata dengan medium), Convex (permukaaan koloni cembung pada medium) 


\section{PEMBAHASAN}

\section{Karakter Isolat Bakteri pada Daging karkas Ayam Broiler yang dari Pasar Swalayan di Kota Pontianak}

Berdasarkan hasil isolasi ditemukan 23 genus bakteri yang mengkontaminasi karkas ayam broiler, yaitu anggota genus Aeromonas, Acetobacter, Alcaligenes, Amphibacillus, Bacillus, Brevibacterium, Camphylobacter, Carnobacterium, Erwinia, Erysipelothrik, Eubacterium, Hafnia, Kluyvera, Klebsiella, Kurthia, Lactobacillus, Listeria, Proteus, Pseudomonas, Shigella, Sporolactobacillus, Serratia, dan Yersinia.

\section{Genus Aeromonas}

Berdasarkan hasil pengamatan secara makroskopis dan mikroskopis serta dilihat dari hasil uji biokimia, isolat (C8) memiliki kesamaan karakter dengan anggota genus Aeromonas yaitu termasuk bakteri gram negatif ukuran sel $3 \mu \mathrm{m}$, bersifat motil Ciriciri makroskopis warna koloni putih, berbentuk bulat, margin lobate dan elevasi convex. Menurut Barrow dan Feltham,1993; Holt et al. (1994) hasil uji biokimia anggota genus Aeromonas termasuk bakteri golongan selulitik yang dapat memfermentasi karbohidrat dengan disertai terbentuknya gas, $\mathrm{H}_{2} \mathrm{~S}$ positif, indol positif, katalase positif, oksidase positif sedangkan uji urease dan SCA negatif. Anggota genus bakteri ini tumbuh pada suhu berkisar $22-28^{\circ} \mathrm{C}$, namun banyak juga yang hidup pada suhu $37^{\circ} \mathrm{C}$. Bakteri ini umumnya ditemukan di perairan dan kotoran.

\section{Genus Acetobacter}

Berdasarkan hasil pengamatan secara makroskopis dan mikroskopis serta uji biokimia, isolat (C4) memiliki kesamaan karakter dengan anggota genus Acetobacter. Menurut Holt et al. (1994) yitu secara makroskopis bakteri anggota genus Acetobacter pada media NA berwarna putih, berbentuk bulat dengan pinggiran koloni rata dan elevasi timbul (convex). Secara mikroskopis bakteri ini termasuk bakteri gram negatif ukuran sel $2 \mu \mathrm{m}$, mampu memfermentasi karbohidrat tidak disertai terbentuknya gas, mampu menghasilkan $\mathrm{H}_{2} \mathrm{~S}$, katalase positif, oksidase negatif, indol positif dan bersifat motil, sedangkan urea dan SCA bersifat negatif.

\section{Genus Alcaligenes}

Berdasarkan hasil pengamatan secara makroskopis dan mikroskopis serta hasil uji biokima, isolat (A9) memiliki kesamaan karakter dengan anggota genus
Alcaligenes. Menurut Holt et al. (1994) secara mikroskopis genus ini termasuk ke dalam bakteri gram negatif, berbentuk batang kecil dengan ukuran sel $4 \mu \mathrm{m}$, sedangkan secara makroskopis bentuk koloni rhizoid, warna koloni putih, tepian lobate (bergelombang) dan permukaan koloni raised (timbul), pertumbuhan optimum $20-37^{\circ} \mathrm{C}$. Berdasarkan hasil uji biokimia pada uji katalase bersifat positif, oksidase positif, genus ini mampu memfermentasi karbohidrat yang disertai dengan terbentuknya gas, tetapi tidak terbentuknya $\mathrm{H}_{2} \mathrm{~S}$, bersifat motil, uji indol, urease dan SCA bersifat negatif yang ditandai tidak terjadinya perubahan warna pada media biakan. Habitat alami dari anggota genus Alcaligenes adalah ditanah dan air, dapat menyebabkan infeksi oportunistik pada manusia.

\section{Genus Amphibacillus}

Berdasarkan hasil pengamatan secara makroskopis dan mikroskopis serta hasil uji biokimia yang dilakukan, isolat (B8) dan (B9) memiliki kesamaan karakter dengan anggota genus Amphibacillus Holt et al. (1994), yaitu secara makroskopis pertumbuhan bakteri anggota genus Amphibacillus pada media NA berwarna putih susu, berbentuk tak beraturan, pinggiran lobate dan elevasi flat. Secara mikroskopis bakteri ini termasuk kedalam bakteri gram positif ukuran sel $3 \mu \mathrm{m}$, tumbuh pada temperatur $25-45^{\circ} \mathrm{C}$, berdasarkan hasil uji biokimia bakteri ini bersifat motil, dapat memfermentasi karbohidrat tidak disertai terbentuknya gas dan $\mathrm{H}_{2} \mathrm{~S}$, uji katalase, oksidase, indol, urea, dan SCA bersifat negatif. Bakteri ini sering ditemukan pada kotoran hewan, rumput dan jerami padi.

\section{Genus Bacillus}

Berdasarkan hasil pengamatan makroskopis dan mikroskopis serta hasil uji biokimia, isolat (A4,A5,A6, A9, A13, A14,B1, B2, B4 dan B5) memiliki kesamaan karakter dengan anggota genus Bacillus. Secara makroskopis, pertumbuhan bakteri pada media NA berwarna putih, bentuk koloninya bulat, permukaan datar dan pinggiran rata. Menurut Cowan dan Steel's (1974), secara makroskopis koloni anggota genus Bacillus pada medium Nutrient Agar (NA) berwarna putih susu, umumnya tahan terhadap panas.

Holt et al. (1994) menyatakan bahwa ciri-ciri mikroskopis bakteri anggota genus Bacillus sel berbentuk batang dan bersifat gram positif, yaitu ukuran sel $4 \mu \mathrm{m}$. Hasil uji biokimiawi menunjukan anggota genus Bacillus dapat memfermentasi karbohidrat tetapi tidak disertai terbentuknya gas 
dan $\mathrm{H}_{2} \mathrm{~S}$. Uji katalase positif, oksidase negatif, bersifat motil, uji indol dan SCA negatif, sedangkan pada uji urease bersifat positif dan ada juga yang bersifat urease negatif.

Menurut Fatmasari (2015) habitat utama anggota genus Bacillus adalah lingkungan dan saluran pencernaan terutama tanah dan air yang menyebabkan bakteri ini punya peluang untuk mencemari produk pangan asal hewan maupun tanaman. Menurut Fardiaz (1992) anggota genus Bacillus merupakan salah satu mikroba perusak pangan yang mampu membentuk spora yang tergolong ke dalam famili Bacillaceae, bersifat aerob sampai anaerob fakultatif. Menurut (Granum dan Parker, 2000) anggota genus Bacillus dapat menyebabkan penyakit infeksi dan intoksikasi. Enterotoksin dapat ditemukan pada bahan pangan atau dibentuk dalam usus

\section{Genus Brevibacterium}

Berdasarkan hasil pengamatan secara makroskopis, dan mikroskopis serta uji biokimia, isolat (C7) memiliki kesamaan karakter dengan anggota genus Brevibacterium, menurut Holt et al.(1994) secara makroskopis bentuk koloni tidak beraturan, warna koloni putih, tepian lobate (bergelombang), permukaan koloni flat (rata), sedangkan secara mikroskopis isolat tersebut termasuk gram positif, bentuk sel batang tak beraturan ukuran sel $4 \mu \mathrm{m}$, pertumbuhan optimum pada suhu $20-35^{\circ} \mathrm{C}$. Hasil uji biokimia menunjukan bahwa anggota genus Brevibacterium dapat memfermentasi karbohidrat yang tidak disertai dengan tebentuknya gas dan $\mathrm{H}_{2} \mathrm{~S}$, uji katalase positif, oksidase positif, sedangkan pada uji indol, motil, urease, dan SCA bersifat negatif.

\section{Genus Camphylobacter}

Berdasarkan hasil pengamatan secara makroskopis dan mikroskopis, serta hasil uji biokimia terhadap isolat (A3) memiliki kesamaan karakter dengan bakteri anggota genus Camphylobacter. Menurut Holt et al. (1994) genus ini termasuk ke dalam bakteri gram negatif dengan bentuk sel basil atau vibrio ukuran sel $2 \mu \mathrm{m}$, berwarna putih abu-abu, bentuk bulat, lobate, dengan elevasi timbul. Setelah dilakukan serangkaian uji biokimia. Bakteri anggota Camphylobacter mampu menghasilkan enzim katalase, oksidase positif, umumnya bersifat motil, urase positif dan tidak membentuk $\mathrm{CO}_{2}$, dan $\mathrm{H}_{2} \mathrm{~S}$, reaksi uji SCA dan Indol bersifat negatif. Secara alami bakteri ini dapat ditemukan pada saluran pencernaan ayam. Menurut Shane (2000) secara umum habitat anggota Camphylobacter ada dalam pencernaan ayam tetapi tidak menyebabkan penyakit, infeksi pada daging ayam dapat terjadi selama ayam masih hidup, kontaminasi pakan, dan air.

\section{Genus Carnobacterium}

Berdasarkan hasil pengamatan secara makroskopis dan mikroskopis serta hasil uji biokimia, isolat (A13) memiliki kesamaan karakter dengan anggota genus Carnobacterium. Menurut Holt et al. (1994), bakteri anggota genus Carnobacterium memiliki bentuk sirkular, berwarna putih, tepian rata, permukaan datar, secara mikroskopis termasuk kedalam gram positif, sel berbentuk batang ramping tersusun tunggal atau berpasangan dan terkadang berbentuk rantai pendek dengan ukuran sel $5 \mu \mathrm{m}$. Pertumbuhan optimum pada suhu $30^{\circ} \mathrm{C}$, Bersifat motil, katalase negatif, oksidase positif, dapat memfermentasi karbohidrat disertai terbentuknya gas dan $\mathrm{H}_{2} \mathrm{~S}$, indol, urease dan SCA bersifat negatif. Anggota genus Carnobacterium dapat ditemukan pada daging dan ikan, seperti anggota spesies $C$. piscicola bersifat patogen pada ikan salmon (Holt $e t$ al, 1994).

\section{Genus Erwinia}

Berdasarkan hasil pengamatan secara makroskopis dan mikroskopis serta hasil uji biokimia, isolat (A8) memiliki kesamaan karakter dengan anggota genus Erwinia. Secara makroskopis, pada media NA bakteri ini berwarna putih, berbentuk tak beraturan (iregular), pinggiran rata dan elevasi timbul. Secara mikroskopis bakteri ini termasuk kedalam bakteri gram negatif berbentuk coccus ukuran sel $2 \mu \mathrm{m}$, pertumbuhan optimum yaitu $27-30{ }^{\circ} \mathrm{C}$ bersifat fakultatif anaerobik (Holt et al., 1994).

Berdasarkan hasil uji biokimia, bakteri ini dapat memfermentasi karbohidrat tidak terbentuk gas dan $\mathrm{H}_{2} \mathrm{~S}$, uji katalase positif, uji oksidase, urease, dan sitrat positif dan tidak dapat menghasilkan indol. Menurut Holt et al. (1994), bakteri anggota genus Erwinia dapat berasosiasi dengan tumbuhan dan bersifat patogen. Keberadaan bakteri ini pada sampel karkas ayam dimungkinkan karena terjadinya kontaminasi silang, yaitu pada saat penjualan produk pangan sayuran dan daging lainnya diletakan berdampingan dengan karkas ayam sehingga memungkinkan bakteri ini terdapat pada karkas ayam. Anggota genus Erwinia jarang ditemukan menginfeksi manusia.

\section{Genus Erysipelothrik}

Berdasarkan pengamatan secara makroskopis dan mikroskopis dan uji biokimia isolat bakteri (B3) 
memiliki kesamaan karakter dengan anggota genus Erysipelothrik. Menurut Holt et al. (1994), secara makrokopis genus ini berwarna bening, dengan bentuk rhizoid, permukaan koloni datar (flat) dan margin berbenang-benang (filamenteus). Hasil pengamatan secara makroskopis bakteri ini termasuk dalam gram positif berbentuk kapsul ukuran sel $5 \mu \mathrm{m}$. Berdasarkan hasil uji biokimia, uji katalase negatif, uji oksidase negatif, bakteri ini mampu memfermentasi karbohidrat disertai dengan terbentuknya gas pada media, bersifat nonmotil, dan bersifat negatif terhadap uji indol, urease, dan SCA. Genus ini mampu tumbuh pada suhu optimum $30-37^{\circ} \mathrm{C}$. Genus Erysipelothink tersebar di alam dan bersifat parasit pada mamalia, unggas dan ikan serta bersifat patogen pada mamalia dan unggas (Holt et al.,1994).

\section{Genus Eubacterium}

Berdasarkan hasil pengamatan secara makroskopis, dan mikroskopis serta uji biokimia, isolat bakteri B6 dan B7 memiliki kesamaan karakter dengan anggota genus Eubacterium. Menurut Holt et al. (1994), secara makroskopis bentuk koloni sel iregular, warna putih susu, tepian filamenteus (seperti benang), permukaan koloni convex, sedangkan secara mikroskopis isolat ini termasuk ke dalam bakteri gram positif, dengan bentuk sel basil, ukuran sel $3 \mu \mathrm{m}$, dan bersifat motil. Berdasarkan hasil uji biokimia anggota genus Eubacterium dapat memferementasi karbohidrat tetapi tidak disertai terbentuknya gas dan $\mathrm{H}_{2} \mathrm{~S}$, urease positif sedangkan uji katalase, oksidase, indol dan sitrat bersifat negatif. Menurut vertebrata (Holt et al., 1994).

anggota genus Eubacterium dapat ditemukan dalam rongga tubuh hewan, dari feses hewan, produk tumbuhan dan tanah, beberapa spesies Eubacterium dapat bersifat patogen oportunistik pada.

\section{Genus Hafnia}

Berdasarkan hasil pengamatan secara makroskopis dan mikroskopis serta uji biokimia, isolat bakteri (A1) memiliki kesamaan karakter dengan anggota genus Hafnia secara makroskopis pada media NA bakteri ini berwarna putih susu, berbentuk bulat, pinggiran rata serta elevasi raised. Secara mikroskopis bakteri anggota genus Hafnia termasuk kedalam gram negatif, dengan bentuk sel kokus ukuran sel $2 \mu \mathrm{m}$, mampu tumbuh pada suhu 30-37 ${ }^{\circ} \mathrm{C}$. Berdasarkan hasil uji biokimia bahwa bakteri anggota genus Hafnia dapat menghasilkan karbohidrat, disertai terbentuknya gas, uji katalase positif, uji oksidase negatif, dan bersifat negatif pada uji indol, urease, $\mathrm{H}_{2} \mathrm{~S}$ dan uji sitrat. Bakteri anggota genus Hafnia umumnya ditemukan pada feses, ditemukan di air, tanah, dan pada produk susu, serta bersifat patogen bagi manusia dan hewan (Holt et al, 1994).

Yulvizar (2013) menyatakan bahwa ada salah satu spesies Hafnia alvei yang berpotensi sebagai probiotik pada ikan gembung. Rodriguez et al. (1998) bahwa bakteri ini dianggap sebagai bakteri patogen oportunistik yang secara alami terdapat pada saluran pencernaan, bakteri anggota genus Hafnia dapat ditemukan pada karkas ayam dikarenakan sistem penjualan karkas ayam broiler dari swalayan berdampingan dengan penjualan produk-produk pangan lainnya sehingga kemungkinan kontaminsi silang dapat terjadi.

\section{Genus Kluyvera}

Berdasarkan hasil pengamatan makroskopis dan mikroskopis dan uji biokimia, isolat bakteri (C3) memiliki kesamaan karakter dengan anggota genus Kluyvera menurut Holt et al. (1994) yaitu secara makroskopis bakteri ini memiliki warna putih, berbentuk bulat, margin rata, dan elevasi flat. Secara mikroskopis bakteri ini termasuk gram negatif ukuran sel $5 \mu \mathrm{m}$, berdasarkan hasil uji biokimia pada uji katalase positif, oksidase negatif, mampu menghasilkan karbohidrat yang disertai terbentuknya gas dan $\mathrm{H}_{2} \mathrm{~S}$, uji indol dan SCA positif, sedangkan uji urease dan oksidase bersifat negatif.

Holt et al. (1994) pertumbuhan optimal bakteri ini yaitu $37^{\circ} \mathrm{C}$ tumbuh pada kondisi secara fakultatif anaerobik dan kemoganotrofik. Anggota genus Kluyvera ini sering ditemukan pada makanan, tanah, kotoran, dan spesimen klinis manusia, saluran pernapasan, saluran kemih dan kadangkadang dalam darah. Anggota genus Kluyvera kadang-kadang bersifat patogen secara oportunistik.

\section{Genus Klebsiella}

Berdasarkan hasil pengamatan secara makroskopis dan mikroskopis serta uji biokimia, isolat bakteri (A2) memiliki kesamaan karakter dengan anggota genus Klebsiella. Menurut Cowan dan Steel's (1974), Memiliki ciri-ciri makroskopis bentuk koloninya bulat tak beraturan, permukaan cembung dan margin rata. Sedangkan ciri-ciri mikroskopis bakteri ini berbentuk sel batang dan bersifat Gram negatif berbentuk kokus ukuran sel $2 \mu \mathrm{m}$, dan tidak motil. Pada media NA koloni anggota genus Klebsiella berwarna putih susu, sel berbentuk 
ovoid sampai batang bersifat aerob dan anaerob fakultatif. Klebsiella masih tergolong anggota family anggota genus Enterobacteriaceae. Klebsiella dapat memfermentasi karbohidrat dan tidak disertai terbentuknya gas, hasil uji indol dan sitrat menunjukan hasil negatif, tetapi tidak dapat menghasilkan $\mathrm{H}_{2} \mathrm{~S}$. Buchanan dan Gibbons (1975) menyatakan bahwa anggota genus Klebsiella tersebar secara merata di alam yaitu di tanah dan di air. Bakteri ini juga ditemukan di saluran pencernaan manusia dan secara alami dapat ditemukan pada saluran pencernaan mamalia. Menurut Ko (2002), anggota genus Klebsiella telah dikenal dalam dunia medis sebagai organisme patogen.

\section{Genus Kurthia}

Berdasarkan hasil pengamatan secara makroskopis, dan mikroskopis serta uji biokimia, isolat bakteri (C5) memiliki kesamaan karakter dengan anggota genus Kurthia. Menurut Holt et al. (1994), secara makroskopis bentuk koloni tak beraturan, warna koloni putih, tepian rhizoid dan permukaan koloni flat (rata). Sedangkan secara mikroskopis termasuk bakteri gram positif, bentuk sel bakteri basil ukuran sel $2 \mu \mathrm{m}$, pertumbuhan optimum pada suhu 25$30^{\circ} \mathrm{C}$. Hasil uji biokimia menunjukan bahwa anggota genus Kurthia dapat memfermentasi karbohidrat tidak disertai terbentuknya gas, terbentuknya $\mathrm{H}_{2} \mathrm{~S}$, bersifat motil, katalase positif, indol positif sedangkan uji oksidase, urease dan SCA bersifat negatif. Anggota genus Kurthia tersebar luas di lingkungan, umumnya dapat ditemukan dari kotoran hewan dan produk daging dan bersifat nonpatogen (Holt et al., 1994).

\section{Lactobacillus}

Berdasarkan hasil pengamatan secara makroskopis dan mikroskopis serta uji biokimia, isolat bakteri (C6) memiliki kesamaan karakter dengan anggota genus Lactobacillus menurut Holt et al. (1994) yaitu secara makroskopis bakteri anggota genus Lactobacillus berwarna putih, bentuk koloni tidak beraturan, margin entire dan elevasi convex, sedangkan secara mikroskopis genus ini termasuk kedalam bakteri gram positif dan bentuk sel kokus ukuran sel $2 \mu \mathrm{m}$. Berdasarkan hasil pengamatan uji biokimia genus ini dapat memfermentasi karbohidrat, tidak disertai dengan terbentuknya gas dan $\mathrm{H}_{2} \mathrm{~S}$, uji katalase positif, uji oksidase negatif, uji indol positif, uji urea dan SCA bersifat negatif. Rahayu, (2007) menyatakan bahwa anggota genus Lactobacillus dapat tumbuh pada temperatur optimum $30-40{ }^{\circ} \mathrm{C}$, umumnya ditemukan pada usus hewan dan manusia, anggota genus Lactobacillus merupakan bakteri asam laktat yang mempunyai potensi sebagai probiotik.

\section{Genus Listeria}

Berdasarkan hasil pengamatan secara makroskopis dan mikroskopis serta hasil uji biokima, dilakukan pada isolat bakteri (C10) memiliki kesamaan karakter dengan anggota genus Listeria. Menurut Holt et al. (1994) bakteri ini memiliki bentuk bulat, berwarna putih, tepian rata dan permukaan koloni datar. Secara mikroskopis termasuk ke dalam gram positif bentuk sel batang ukuran sel $2 \mu \mathrm{m}$, hasil uji biokimia menunjukan bahwa anggota genus Listeria bersifat motil, hidup secara anaerob fakultatif, tumbuh pada suhu optimum $30-37^{\circ} \mathrm{C}$ bersifat chemoorganotroph, dapat memfermentasi karbohidrat yang tidak disertai terbentuknya gas dan $\mathrm{H}_{2} \mathrm{~S}$. Katalase dan indol bersifat positif, sedangkan uji oksidase, urease, dan SCA bersifat negatif (Barrow \& Feltham, 1993)

Anggota genus Listeria dapat ditemukan pada produk makanan mentah seperti daging yang kurang dimasak, hot dog, sayuran, dan seafood (Churchill et al., 2010). Abdelgadir et al. (2009) menyatakan bahwa kontaminasi bakteri anggota genus Listeria dapat terjadi di peternakan, tempat pemotongan ternak, pemprosesan makanan siap santap, pengawatan makanan, penyimpanan maupun selama transportasi.

\section{Genus Proteus}

Berdasarkan pengamatan secara makroskopis dan mikroskopis serta hasil uji biokimia, isolat bakteri (C9) memiliki kesamaan karakter dengan anggota genus Proteus. Secara makroskopis ciri-ciri pertumbuhan bakteri ini pada media NA yaitu koloni berwarna putih berbentuk sirkular, margin berbentuk lobate, dan elevasi convex. Menurut Quinn et al. (2004) secara mikroskopis bakteri anggota genus proteus termasuk kedalam kelompok gram negatif berbentuk basil ukuran sel $2 \mu \mathrm{m}$, tumbuh pada temparatur $37^{\circ} \mathrm{C}$, anggota genus proteus adalah salah satu anggota famili Enterobacteriaceae.

Berdasarkan hasil uji biokimia menunjukan uji katalase positif, oksidase negatif, dapat memfermentasi karbohidrat tidak terbentuknya gas, $\mathrm{H}_{2} \mathrm{~S}$ positif, uji indol dan urea positif, sedangkan uji SCA bersifat negatif. Bakteri ini sering ditemukan di tanah, air dan pada usus manusia dan hewan, serta bersifat patogen bagi manusia (Holt et al., 1994). Menurut Manos dan Belas (2006), anggota genus Proteus dapat ditemukan pada hewan. 
menyatakan bahwa anggota genus Proteus ini dapat menyebabkan infeksi peradangan urin dan menyebabkan infeksi pada luka serta bersifat patogen oportunistik (Holt et al.,1994)

\section{Pseudomonas}

Berdasarkan pengamatan secara makroskopis dan mikroskopis serta hasil uji biokimia, isolat bakteri (A7) memiliki kesamaan karakter dengan anggota genus Pseudomonas. Menurut Barrow dan Feltham 1993, serta Holt et al. (1994), secara makroskopis pada media NA bakteri ini berwarna putih, berbentuk iregular, dengan tepian lobate dan permukaan datar (flat), sedangkan secara mikroskopis termasuk gram negatif berbentuk batang pendek ukuran sel $3 \mu \mathrm{m}$. Hasil uji biokimia menunjukan bahwa anggota genus Pseudomonas dapat memfermentasi karbohidrat tetapi tidak terbentuknya $\mathrm{H}_{2} \mathrm{~S}$ dan gas, bersifat motil, katalase positif, SCA positif, sedangkan uji oksidase dan indol bersifat negatif. Bakteri ini tumbuh secara anaerob, chemoorganotrophic.

Anggota genus Pseudomonas dapat ditemukan di lingkungan alami baik di air, tanah, tanaman bahkan di dalam air limbah. Beberapa jenis bakteri ini seperti anggota spesies P.putida, dan P.flurescens dapat ditemukan pada sistem pencernaan mamalia (Willey et al.,2008). Anggota genus Pseudomonas merupakan salah satu jenis mikroflora normal pada saluran pencernaan dan kulit manusia, namun terkadang juga dapat berubah menjadi patogen oportunistik yang menyebabkan bronkopneumonia kronis saat kondisi imun tubuh menurun, kondisi serupa juga sering ditemukan pada hewan yang menderita Pneumonia dan gangguan saluran urin (Tellez et al., 2010).

\section{Genus Shigella}

Berdasarkan pengamatan secara makroskopis dan mikroskopis serta hasil uji biokimia, isolat $(\mathrm{C} 1, \mathrm{C} 2)$ memiliki kesamaan karakter dengan anggota genus Shigella menurut Cowan dan Steel's (1974), secara makroskopis anggota genus Shigella bentuk koloninya bulat, transparan, permukaan cembung dan pinggiran bergelombang. Menurut Holt et al. (1994), secara makroskopis koloni anggota genus Shigella pada medium Nutrient Agar (NA) berwarna keabu-abuan, secara mikroskopis berbentuk sel batang dan bersifat Gram negatif ukuran sel $2 \mu \mathrm{m}$. Berdasarkan hasil uji biokimia, anggota genus Shigella dapat memfermentasi karbohidrat dan tidak dapat membentuk gas dan $\mathrm{H}_{2} \mathrm{~S}$, bersifat nonmotil, SCA positif, sedangkan uji indol, dan urease bersifat negatif. Menurut Nugroho
(1996), bakteri anggota Shigella merupakan bakteri berbentuk batang pendek, tidak berflagel, tidak berkapsul, tidak membentuk spora, tidak bergerak dan merupakan bakteri patogen pada usus yang dikenal sebagai agen penyebab penyakit disentri basiler.

\section{Genus Sporolactobacillus}

Berdasarkan hasil pengamatan makroskopis dan mikroskopis serta uji biokimia, isolat bakteri (A16) memiliki kesamaan karakter dengan anggota genus Sporolactobacillus menurut Holt et al. (1994) yaitu secara makroskopis pertumbuhan bakteri ini pada media NA berwarna putih, bentuk sirkular, tepian rata dan permukaannya flat, secara mikroskopis bakteri ini termasuk gram positif, berbentuk basil ukuran sel $4 \mu \mathrm{m}$. Berdasarkan hasil uji biokimia bakteri ini bersifat motil, uji katalase negatif oksidase positif, mampu memfermentasi karbohidrat dengan terbentuk nya asam disertai terbentuk gas, tetapi tidak terbentuknya $\mathrm{H}_{2} \mathrm{~S}$, uji urea positif, sedangkan uji indol dan SCA negatif. Bakteri ini tumbuh pada suhu optimum $35^{\circ} \mathrm{C}$, ditemukan pada pakan ayam dan sekitar lingkungan tanah.

\section{Genus Serratia}

Berdasarkan hasil pengamatan secara makroskopis dan mikroskopis serta hasil uji biokimia, isolat bakteri (A12) memiliki kesamaan karakter dengan anggota genus Serratia, karakter yang ditemukan sesuai menurut Holt et al. (1994) yaitu bakteri ini termasuk ke dalam gram negatif dan masuk dalam anggota famili Enterobateriaceae bentuk sel batang pendek ukuran sel $5 \mu \mathrm{m}$. Secara mikroskopis bakteri ini dapat memfermentasi karbohidrat disertai dengan terbentuknya gas, tetapi tidak membentuk $\mathrm{H}_{2} \mathrm{~S}$, uji indol dan urea bersifat negatif, SCA bersifat positif. memiliki pertumbuhan optimum pada temperature $30-37^{\circ} \mathrm{C}$. Sedangkan hasil uji biokimia menunjukan bahwa bakteri ini bersifat motil karena anggota genus Serratia memiliki flagella peritrik.

Menurut Rao et al. (1998), bakteri anggota genus Serratia dapat ditemukan di tanah, air, dan di permukaan tanaman, anggota genus Serratia dapat menghasilkan enzim protease. Berbagai jenis bakteri anggota spesies Bacillus sp, Lactobacillus sp, Pseudomonas sp, Closteridium sp, dan Serratia sp, merupakan bakteri penghasil enzim protease yang berpotensi membantu proses pencernaan pada hewan. 


\section{Genus Yersinia}

Berdasarkan hasil pengamatan makroskopis dan mikroskopis serta hasil uji biokimia, isolat bakteri (A11) memiliki kesamaan karakter dengan anggota genus Yersinia. Menurut Holt et al. (1994), warna koloni putih pada media NA, bentuk koloni rhizoid, pinggiran berbenang-benang, dan elevasi raised. Secara mikroskopis bakteri ini termasuk gram negatif, bentuk sel basil ukuran sel $4 \mu \mathrm{m}$, dan mampu tumbuh pada suhu $28-30^{\circ} \mathrm{C}$. Berdasarkan hasil uji biokimia, bakteri ini bersifat nonmotil fakultatif anaerobic, dapat memfermentasi karbohidrat tidak disertai dengan terbentuknya gas dan $\mathrm{H}_{2} \mathrm{~S}$. Sebagian anggota genus Yersinia mampu menghasilkan indol dan ada juga yang tidak dapat menghasilkan indol. Katalase positif, uji SCA positif, sedangkan uji urea negatif, bakteri ini umumnya dapat menginfeksi manusia, hewan terutama jenis unggas, tanah, produk susu dan makanan lain.

Menurut Faiza (2013) bakteri anggota genus Yersinia adalah salah satu anggota famili Enterobacteriaceae yang mengkontaminasi bahan pangan yang hidup di perairan dan dapat menimbulkan infeksi pada manusia. Menurut Mair (1973), beberapa anggota genus Yersinia yang dapat bersifat patogen bagi manusia dan hewan ialah anggota spesies Yersinia enterocolitica menyebabkan infeksi pada usus manusia dan hewan, yaitu anggota spesies Yersinia pestis menyebabkan penyakit pes, dan Yersinia pseudotuberculosis menginfeksi limpa pada hewan dan menyebabkan penyakit seperti tuberculosis. Penularannya ke manusia berasal dari daging yang terinfeksi dan kurang matang serta bersifat patogen bagi banyak spesies hewan. Terkadang pada manusia menyebabkan adenitis mesentrika, diare kronis, dan septikemia berat.

\section{DAFTAR PUSTAKA}

Abdelgadir, A.M.M.A., K,K, Srivastava K,K, \& Reddy, P.G, 2009, Detection Of Listeria Monocytogenes In Readyto-Eat Meat Products, American Journal of Animal and Veterinary Sciences, vol. 4, no. 4, hal. 101-107

Albiner S, 2002, Bahan Tambahan Makanan, Fakultas Kesehatan Masyarakat, Universitas Sumatera Utara

Barrow, GI, \& Feltharn, RKA, 1993, Cowan And Steel's Manual For The Identification Of Medical Bacteria, Cambridge University Press, United Kingdom
Buchanan, R.E, \& Gibbons, N.E.R, 1975, Bergey's Manual of Determinative Bacteriology, Baltimore, the Williams and Wilkins Company, New York.

Cowan, S.T, \& Steel, K.J, 1974, Manual For The Identification of Medical Bacteria, $2^{\text {nd }} \mathrm{ed}$, Cambridge University Press, London

Churchill, R.L.T., H. Lee \& J.C. Hall, 2006, Detection of Listeria monocytogenes and the toxin listeriolysin O in food, Journal Microbiol Methods, vol. 64, no. 2 , hal. $141-170$

Fardiaz, S, 1992, Mikrobiologi Pengelolaan Pangan, Departemen Pendidikan dan kebudayaan Direktorat Jendral Pendidikan Tinggi Pusat Antar Universitas Pangan dan Giz, Institut Pertanian Bogor, Bogor

Fatmasari, 2015, Uji Sensitivitas Antibiotik Kloramfenikol Siprofloksasin, Eritromisin dan Klindamisin Terhadap Bacillus cereus yang diisolasi dari Daging Sapi di Pasar Tradisional dan Pasar Moderen Kota Makasar. Skripsi, Fakultas Kedokteran, Universitas Hasanuddin Makasar

Faiza, DA, 2013, Kepadatan Yersinia sp yang di Isolasi dari Ikan Mas (Cyprinus carpio, L), Jurnal Entropi, vol. 8, no. 1, hal. 593-597

Granum, PE, dan Baird-Parker, TC, 2000, Bacillus sp, dalam: Lund BM Baird-Parker, TC, and Gauld, GW, (ed), The Microbiological Safety and Quality of Food, AspenPublishers, inc Gaithersburg, Maryland, vol. II, no. 1, hal. 10291039

Holt J.G., Krig N.R., Sneath P., Staley J., \& Williams S, 1994, Bergey's Manual of Determinative Bacteriology $9^{\text {th }}$ Edition, Philadelphia (USA): Lipincott Williams and Wilkins Company

Irawati, N, \& Hanurawaty,YN, 2014, Penggunaan Kemasan Plastik Jenis PE (Polythylen), PP (Polypropylen) dan Plastik Wrap Terhadap Angka Kuman pada Daging, Jurnal Visikes, vol. 13, no. 1, hal. 21-27

Ko, WC, 2002, Community-Acquired Klebsiella pneumonia Bacteremia:Global Differences in Clinical Patterns, National Cheng Kung University Medical College, Taiwan

Mair, NS,1973, Yersiniosis in wildlife and its public health implications, Journal of Wildlife Disease, vol. 9 , no. 2, hal. 1-8 
Manos J, \& Belas R, 2006, The Genera Proteus, Providencia, and Morganella Prokaryotes Journal Chapter, vol. 6, no. 2, hal 245-269

Nugroho, E, 1996, Mikrobiologi Kedokteran, EGC, Jakarta

Quinn, PJ, Cater, ME, Markey,B, \& Carter GR, 2004, Clinical Veterinary Microbiology, Ed ke-4, New York, Mosby

Rao, MB, Tanksale AM, Ghatge MS, \& Deshpande VV, 1998, Molecular and Biotechnological Aspects Of Microbial protease, Microb Mol Biol Rev vol.62, no.16, hal. 1092-2172

Rahayu, E, \& Purwandhani, S., 2007, Isolasi dan Seleksi Lactobacillus yang Berpotensi Sebagai Agensia Probiotik, Agritech, vol. 23, no. 2, hal. 3-5

Rodriguez LA, Gallardo CS, Acosta F, Nieto TP, Acosta B, dan Real F, 1998, Hafnia alvei as an Opportunistic Pathogen Causing Mortality in Brown Trout, Salmo trutta L, Journal of Fish Diseases, vol. 21, no. 2, hal 365-369
Shane, SM, 2000, Campylobacter Infection of Commercial poultry, Rev. Sci. tech. Off. Int. Epiz, vol 19, no 2, hal 376-395

Triyantini, Abubakar, Roswita, S, \& Hadi, S, 2000, Mutu Karkas Ayam Hasil Teknik Pemotongan Berbeda, Seminar Nasional dan Veteriner Balai Penelitian Ternak, hal. 391-396

Tellez, RA, Guemes, FS, Casas EMC, \& Castro RH, 2010, Bacteria and Yeast Normal Microbiota From Respiratorytract and Genital Area of Bottlenose Dolphins (Tursiops truncatus), Jurnal Microbial And Microb Biotech, vol. 1, no. 3, hal 666-673

Willey, JM, Sherwood LM, Woolverton CJ, 2008, Prescott, Harley, and klein's microbiology, Ed ke-7, New York, McGraw-Hill

Waluyo L, 2008, Metode Analisis Mikrobiologi, UMM Press, Malang

Yulvizar, C, 2013, Isolasi dan Identifikasi Bakteri Probiotik pada Rastrelliger sp, Jurnal Biospecies. vol. 6 , no. 2, hal.1-7 